\title{
SELECTION OF OPTIMAL RENEWABLE ENERGY INVESTMENT PROJECT VIA FUZZY ANP
}

DOI: 10.17261/Pressacademia.2018.827

JEFA- V.5-ISS.2-2018(7)-p.224-233

\author{
Serhan Hamal ${ }^{1}$, Ozlem Senvar ${ }^{2}$, Ozalp Vayvay ${ }^{3}$ \\ ${ }^{1}$ Marmara University, Department of Industrial Engineering, Kadikoy, Istanbul, Turkey \\ serhanhamal@gmail.com, ORCID: 0000-0002-0086-1025 \\ 2 Marmara University,Department of Industrial Engineering, Kadikoy, Istanbul, Turkey \\ ozlem.senvar@marmara.edu.tr, ORCID: 0000-0003-3648-9445 \\ ${ }^{3}$ Marmara University, Department of Industrial Engineering, Kadikoy, Istanbul, Turkey \\ ozalp@marmara.edu.tr,ORCID: 0000-0003-0504-3395
}

To cite this document

Hamal, S., Senvar, O., Vayvay, O. (2018). Fuzzy anp based approach for selecting optimal renewable energy investment project. Journal of Economics, Finance and Accounting (JEFA), V.5(2), p.224-233.

Permemant link to this document: http://doi.org/10.17261/Pressacademia.2018.827

Copyright: Published by PressAcademia and limited licenced re-use rights only.

\section{ABSTRACT}

Purpose - This study aims to determine the optimal renewable energy investment project providing a guideline to the investors in decision making process.

Methodology - This study presents a comprehensive and solid mathematical approach considering the assessment of the ambiguities in the preferences of the decision maker for selection of the optimal renewable energy investment project via fuzzy analytic network process (FANP). FANP captures vagueness along with uncertainties in the evaluation.

Findings - After FANP method had been implemented for the considered problem, Hydropower with $31 \%$ of importance is selected as optimum renewable energy investment project for the firm.

Conclusion- This study provides a realistic assessment of energy resources and the consideration of the ambiguities presented in the preferences of the decision maker.

Keywords: Multi Criteria Decision Analysis (MCDA), Fuzzy Logic, Fuzzy Analytic Network Process (FANP), Triangular Fuzzy Number, Renewable Energy (RE).

JEL Codes: Q42, G11, D81

\section{INTRODUCTION}

Energy is the driving force behind economic development and industrialization Nowadays, energy demand is one of the biggest problems for the environment, economy, and development. Fossil fuel reserves are limited and their usage has significant environmental effects so renewable energy sources have been a focus of study because they are renewable, sustainable, and environmentally friendly. Renewable energy sources have to overcome environmental, socio-economic, technical, and institutional barriers. Renewable energy decision making can be considered as a multi criteria decision making problem with correlating criteria and alternatives. Real life decision making situations should be considered when selecting and evaluating an optimal renewable energy investment project, the decision makers or stakeholders can be uncertain about their own level of preference, due to incomplete information or knowledge, complexity and uncertainty within the decision environment. Therefore, it's better to make project selection and assessment under fuzzy conditions.

Energy is the driving force behind economic development and industrialization around the world. Today, energy demand is one of the biggest problems world- wide, with enormous implications for the environment, economy, and development. Due to the fact that fossil fuel reserves are limited and their usage has significant environmental effects, renewable energy sources have been a focus of study because they are renewable, sustainable, and environmentally friendly. The exploitation of renewable energy sources aims not only towards less dependence on fossil fuels, but also protection of the environment. Renewable energy sources have to overcome environmental, socio-economic, technical, and institutional barriers. (Mourmouris and Potolias,2013). Generating electricity from renewable energy sources has become a high priority in the energy policy strategies at a national level as well as on a global scale (Benli, 2013). Renewable energy sources for electricity production continued to improve and are gradually replacing fossil fuel-based power plants (Noorollahi et al.,2016). 
Renewable energy sources are the fastest growing energy source in the world and various projections indicate that these resources will have huge contribution in the future (Jefferson, 2006).

There are both quantitative and qualitative factors involved in decision making process of selection of optimal renewable energy investment project. As the complexity of decisions increases, it becomes more difficult for decision makers to determine an optimal alternative. Selecting the appropriate source of energy in which to be invested is a task that involves different factors and policies. Renewable energy decision making can be considered as a multi criteria decision making (MCDM) problem with correlating criteria and alternatives. There are conflicting aspects which should be taken into account due to increasing complexity of the social, technological, environmental and economic factors that affect various interest groups or stakeholders needs.

This study is handled for the energy strategy decision making problem to help energy investors to determine the optimal renewable energy investment project. For this aim, this study presents an evaluation method for selection of the optimal renewable energy investment project using fuzzy ANP (FANP) approach. The rest of the paper is organized as follows: In section 2, literature review is presented. Section 3 summarizes FANP methodology. In section 4, application study and results are provided. Conclusion along with recommendations are given in the final section.

\section{LITERATURE REVIEW}

The use of multi criteria decision analysis (MCDA) techniques provides a reliable methodology to rank alternative renewable energy resources, technologies and projects in the presence of different objectives and limitations. Multi-criteria analyses are often applied to assess and compare the sustainability of different renewable energy technologies or energy plans with the aim to provide decision-support for choosing the most sustainable and suitable options either for a given location or more generically (Troldborg et. Al., 2014).

Zhou (2012) highlighted that analytic hierarchy process (AHP) or analytic network process (ANP) has been utilized as a suitable multi criteria decision analysis tool for project selection and evaluation due to the fact that both of them can deal with qualitative and quantitative information at the same time. ANP can take into account the interaction and feedback relationships between criteria and/or indices.

Real life decision making situations should be considered when selecting and evaluating an optimal renewable energy investment project, the decision makers or stakeholders can be uncertain about their own level of preference, due to incomplete information or knowledge, complexity and uncertainty within the decision environment. Due to the vagueness and uncertainty on the judgments of decision makers, the crisp pairwise comparison in the conventional AHP/ANP seems insufficient and imprecise to capture the right judgments of decision makers. It's better to make project selection and assessment under fuzzy conditions. Fuzzy ANP is very useful in circumstances where there is a high degree of interdependence between various attributes of the project, for instance when the result of one criterion also affects the others (Mohanty et al, 2005).

Taha and Daim (2013) mentioned that uncertainties and vagueness are inevitable in a decision making process. Fuzzy logic is integrated to overcome the ambiguities in the preferences. Kahraman et al (2009) executed fuzzy axiomatic design and fuzzy AHP for multi attribute selection among renewable energy alternatives. Kahraman and Kaya (2010) proposed a fuzzy multi criteria decision making methodology which can evaluate linguistic terms, fuzzy numbers, and precise numerical values. Their proposed methodology was applied to the case of Turkey to determine the energy policy by sorting the best available alternatives.

In Table 1, researches regarding MCDM based methods used for renewable energy related problems are given. Beccali et al. (2003) have done an application of the multicriteria decision-making methodology used to assess an action plan for the diffusion of renewable energy technologies at regional scale. They compared the Electre Multicriteria Analysis Approach to a Fuzzy-Sets Methodology. They showed differences among these two different approachs.. Advantages and drawbacks of both methods were explored and some suggestions were proposed. Stein(2013) used AHP to rank electricity producing technologies based on a comprehensive set of 11 factor representing financial, technical, environmental and socioeconomic-political considerations. Zhang et al. (2015) developed an improved MCDM method based on fuzzy measure and integral and applied to evaluate four primary clean energy options for Jiangsu Province, China Haddad B. et al.(2017) used AHP method to rank renewables energy sources for the Algerian electricity system. Solar power was shown to be particularly well suited for Algeria, outperforming most of the other renewable options in a large set of highly weighted criteria. Wind power ranked second, followed by biomass, geothermal and lastly by hydropower. 
Table 1: Studies Regarding MCDM Based Methods Used For Renewable Energy Selecion Problem

\begin{tabular}{|l|l|l|}
\hline Research Articles & Utilized Technique & Studied Problem \\
\hline Beccali et al. (2003) & Electre & $\begin{array}{l}\text { Decision-Making In Energy Planning. Application Of The } \\
\text { Electre Method At Regional Level For The Diffusion Of } \\
\text { Renewable Energy Technology. }\end{array}$ \\
\hline Stein(2013) & Analytic Hierarchy Process (AHP) & $\begin{array}{l}\text { A Comprehensive Multi-Criteria Model To Rank Electric } \\
\text { Energy Production Technologies. }\end{array}$ \\
\hline Zhang et al. (2015) & $\begin{array}{l}\text { The Hybrids Method of EWM (entropy } \\
\text { weight method), Shapley Values and } \\
\text { Marichal Entropy }\end{array}$ & $\begin{array}{l}\text { Evaluating Clean Energy Alternatives For Jiangsu, China: } \\
\text { An Improved Multi-Criteria Decision Making Method. }\end{array}$ \\
\hline $\begin{array}{l}\text { Haddad B. et } \\
\text { al.(2017) }\end{array}$ & AHP & $\begin{array}{l}\text { A Multi-Criteria Approach To Rank Renewables For The } \\
\text { Algerian Electricity System. }\end{array}$ \\
\hline
\end{tabular}

Examples of the researches regarding fuzzy MCDM based methods used for renewable energy related problems are as follows: Kahraman et al. (2009) used Fuzzy Axiomatic Design and Fuzzy Analytic Hierarchy Process methods for the selection among renewable energy alternatives. They made a comparison between Fuzzy Axiomatic Design and Fuzzy Analytic Hierarchy Process methods to the selection of the best renewable energy alternative. They determined the most appropriate renewable energy alternative for Turkey.Kaya and Kahraman(2011) proposed a modified fuzzy TOPSIS methodology for the selection of the best energy technology alternative by modifying Chen's (2000) weighting procedure using fuzzy comparison matrices of extent analysis. They used the weights of the extent analysis and implemented the steps of TOPSIS algorithm. Finally they found wind energy is the best alternative among other energy technologies. Tasri and Susilawati (2014) developed a selection methodology and to determine the most appropriate renewable energy sources for electricity generation for Indonesia.They used fuzzy AHP method and Hydro power was found to be the best renewable energy source, followed by geothermal, solar, wind energy and biomass.

Dong and Li (2016) examined project investment decision making with fuzzy information (PIDMFI) and revealed features, state of the art, interrelations, and research directions of existing methodologies for PIDMFI.

\section{DATA AND METHODOLOGY}

The analytical network process (ANP) is a method based on but different from AHP. ANP takes into account the self feedback among criteria or indices with a network structure, while AHP uses a hierarchical structure and does not include self feedback loops (Saaty and Vargas, 2006). ANP takes into account of all kinds of interactions systematically. Many decision problems cannot be structured hierarchically because they involve the interaction and dependence of higher level elements in a hierarchy on lower level elements. Therefore, ANP is represented by a network, rather than a hierarchy (Saaty, 2005).

Fuzzy ANP method adapts the subjectivity of human judgment as being expressed in natural language. Reaching a conclusion is sometimes impractical and unclear to acquire exact judgments in pairwise comparisons. For example, the decision maker may say with confidence that alternative $A$ is very strongly more preferred than alternative $B$ with respect to a criterion, but when asked to give an exact ratio of how strongly $A$ dominates $B$, difficulties would be arisen in giving a precise numerical value. For another example, in a comparison between an $X$ and $Y$ elements, it can be said that $X$ is strongly preferred than $Y$. But if the question "how strongly $X$ dominates $Y$ " is asked, then the answer will not be exact. There is always an uncertainty in a decision making process. Fuzzy based method, Fuzzy ANP, can meet required formation for uncertain and vague pairwise comparisons (Boran and Goztepe, 2010).

Due to the complexity and uncertainty involved, and the inherent subjective nature of human judgments, it is sometimes unrealistic and infeasible to acquire exact judgments in pairwise comparisons (Promentilla,et al.,2008). It is more natural or easier to provide verbal judgments when giving subjective assessment. It is difficult for conventional quantification to express reasonably situations, which are apparently complex or hard to define. Linguistic variable can essentially be used in such situations (Lin, et al.,2009).

In Table 2, linguistic scales include "equally important," "weakly important," "essentially important," "very strongly important," and "absolutely important" with respect to fuzzy level scale. Notably, each membership function of linguistic scale is defined by three parameters of the symmetric triangular fuzzy number. 
Chang (1996) introduced fuzzy AHP (FAHP) with the use of triangular fuzzy numbers for pairwise comparison scale of FAHP. In this study, Chang's extent analysis is handled for FANP in selection of the optimal renewable energy investment project, by allowing triangular fuzzy numbers for pairwise comparisons and determining fuzzy weights. Zhu et al. (1999) improved formulation of comparing the triangular fuzzy number's size.

Table 2: Membership Function of Linguistic Scale Associated with Pairwise Comparisons

\begin{tabular}{|c|c|c|c|c|}
\hline Linguistic scale & $\begin{array}{l}\text { intensity of } \\
\text { importance }\end{array}$ & $\begin{array}{l}\text { Triangular } \\
\text { fuzzy scale }\end{array}$ & $\begin{array}{l}\text { Triangular fuzzy } \\
\text { reciprocal scale }\end{array}$ & Explanation \\
\hline Equally important & 1 & $(1,1,1)$ & $(1,1,1)$ & $\begin{array}{l}\text { two activities contribute equally to the } \\
\text { objective }\end{array}$ \\
\hline Intermediate & 2 & $(1,2,3)$ & $(1 / 3,1 / 2,1)$ & \\
\hline Weakly important & 3 & $(2,3,4)$ & $(1 / 4,1 / 3,1 / 2)$ & $\begin{array}{l}\text { experience and judgment slightly favor one } \\
\text { activity over another }\end{array}$ \\
\hline Intermediate & 4 & $(3,4,5)$ & $(1 / 5,1 / 4,1 / 3)$ & \\
\hline $\begin{array}{l}\text { Essentially } \\
\text { important }\end{array}$ & 5 & $(4,5,6)$ & $(1 / 6,1 / 5,1 / 4)$ & $\begin{array}{l}\text { experience and judgment strongly favor one } \\
\text { activity over another }\end{array}$ \\
\hline Intermediate & 6 & $(5,6,7)$ & $(1 / 7,1 / 6,1 / 5)$ & \\
\hline $\begin{array}{l}\text { Very strongly } \\
\text { important }\end{array}$ & 7 & $(6,7,8)$ & $(1 / 8,1 / 7,1 / 6)$ & $\begin{array}{l}\text { an activity is favored very strongly over } \\
\text { another }\end{array}$ \\
\hline Intermediate & 8 & $(7,8,9)$ & $(1 / 9,1 / 8,1 / 7)$ & \\
\hline $\begin{array}{l}\text { Absolutely } \\
\text { important }\end{array}$ & 9 & $(9,9,9)$ & $(1 / 9,1 / 9,1 / 9)$ & $\begin{array}{l}\text { the evidence favoring one activity over another } \\
\text { is of the highest possible order of affirmation a } \\
\text { reasonable assumption }\end{array}$ \\
\hline
\end{tabular}

Note: Reciprocals scale indicates if activity $i$ has one of the above nonzero numbers assigned to it when compared with activity $j$, then $j$ has the reciprocal value when compared with $\mathrm{i}$

In this study, the formulations and steps of Chang's extent analysis approach are used as follows:

Let $X=\left\{x_{1}, x_{2}, \ldots \ldots x_{3}\right\}$ be an object set, and $U=\left\{u_{1}, u_{2}, \ldots \ldots u_{3}\right\}$ be a goal set. According to Chang's extent analysis, each objects is taken and performed extent analysis for each goal $(g i)$ respectively. Therefore, $m$ extent analysis values for each object are obtained and Lin, et al. (2009) defined each object as follows:

$$
M_{g i}^{1}, M_{g i}^{2}, \ldots . ., M_{g i}^{m} \quad \text { for } i=1, \ldots, n
$$

where all the $M_{g i}^{j}$ for $j=1,2, \ldots . ., m$ are triangular fuzzy numbers whose parameters are $I$ (the least possible value), $m$ (the most possible value), and $u$ (the largest possible value), respectively. A triangular fuzzy number is represented as $(l, m, u)$.

The steps of the Chang's extent analysis can be given as follows:

Step 1. The value of fuzzy synthetic extent with respect to the $i^{\text {th }}$ object is defined as follows:

$$
S i=\sum_{J=1}^{m} M_{g i}^{j}(x)\left[\sum_{i=1}^{n} \sum_{j=1}^{m} M_{g i}^{j}\right]^{-1}
$$

where $(x)$ denotes the extended multiplication of two fuzzy numbers. For obtaining $\sum_{j=1}^{m} M_{g i}^{j}$, the fuzzy addition operation of $m$ extent analysis values for a particular matrix is performed as follows:

$$
\sum_{J=1}^{m} M_{g i}^{j}=\left(\sum_{j=1}^{m} l j, \sum_{j=1}^{m} m j, \sum_{j=1}^{m} u j\right), \quad \text { for } i=1,2, \ldots, n
$$

and for obtaining $\left[\sum_{i=1}^{n} \sum_{j=1}^{m} M_{g i}^{j}\right]^{-1}$, the fuzzy addition operation is performed as follows: 
$M_{g i}^{j}$ for $j=1,2, \ldots \ldots, m$ values such that

$$
\sum_{i=1}^{n} \sum_{J=1}^{m} M_{g i}^{j}=\left(\sum_{j=1}^{n} l i, \sum_{j=1}^{n} m i, \sum_{j=1}^{n} u i\right)
$$

And, the inverse of the vector is computed as follows:

$$
\left[\sum_{i=1}^{n} \sum_{j=1}^{m} M_{g i}^{j}\right]^{-1}=\left(\left(\sum_{i=1}^{n} u i\right)^{-1},\left(\sum_{i=1}^{n} m i\right)^{-1},\left(\sum_{i=1}^{n} l i\right)^{-1}\right)
$$

Step 2. The degree of possibility of $M_{2}=\left(l_{2}, m_{2}, u_{2}\right) \geq M_{1}=\left(l_{1}, m_{1}, u_{1}\right)$ is defined as follows:

$$
V\left(M_{2} \geq M_{1}\right)=\sup _{y \geq x}\left[\min \left(M_{1}(x), M_{2}(y)\right)\right]
$$

which can be equivalently expressed as follows:

$$
V\left(M_{2} \geq M_{1}\right)=h g t\left(M_{1} \cap M_{2}\right)=M_{2}(d)
$$

where $d$ is the ordinate of the highest intersection point $D$ between $u M_{1}$ and $u M_{2}$, as shown in Figure 1 .

Figure 1: The Intersection between M1 and M2. (source: Lin, et al.,2009)

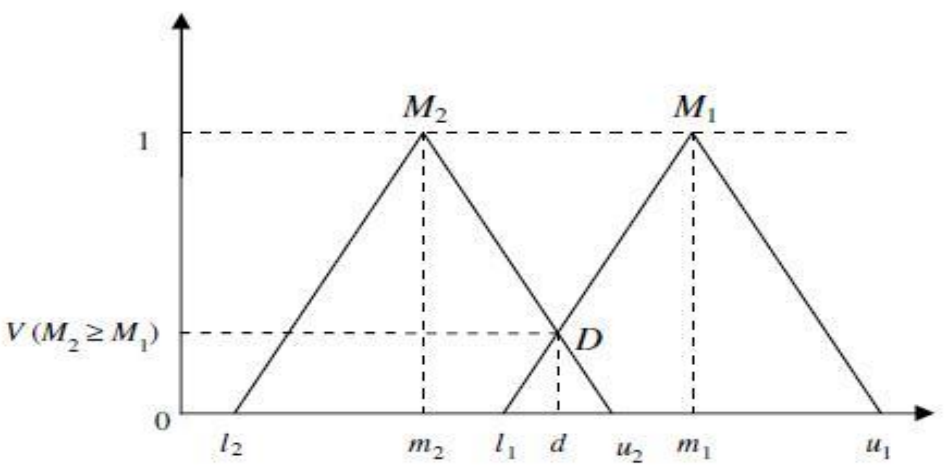

The ordinate of $D$ is defined as follows:

$$
V\left(M_{2} \geq M_{1}\right)=h g t\left(M_{1} \cap M_{2}\right)=M_{2}(d)=\left(l_{1}-u_{2}\right) /\left(m_{2}-u_{2}\right)-\left(m_{1}-l_{1}\right)
$$

To compare $U_{M 1}$ and $U_{M 2}$; we should need both the values of $V\left(M_{1} \geq M_{2}\right)$ and $V\left(M_{2} \geq M_{1}\right)$.

Step 3. The degree of possibility for a convex fuzzy number to be greater than $k$ convex fuzzy numbers Mi for $i=1,2, \ldots k$ can be defined as follows:

$V\left(M \geq M_{1}, M_{2}, \ldots, M_{k}\right)=V\left[\left(M \geq M_{1}\right)\right.$ and $\left(M \geq M_{2}\right)$ and $\ldots$ and $\left.\left(M \geq M_{k}\right)\right]=\min V\left(M \geq M_{i}\right)$, for $i=1,2, \ldots, k$

Assume that

$$
d^{\prime}(\mathrm{Ai})=\min \mathrm{V}(\mathrm{Si} \geq \mathrm{Sk})
$$

for $k=1,2, \ldots, n ; k \neq i$. Then the weight vector is defined as in the following way:

$$
W^{\prime}=\left(d^{\prime}(\mathrm{A} 1), d^{\prime}(\mathrm{A} 2), \ldots ., d^{\prime}(\mathrm{An})\right)^{T}
$$

where $A i$ for $i=1,2, \ldots, n$ corresponding to $n$ elements.

Step 4. Via normalization, the normalized weight vectors are evaluated as follows:

$$
W=(d(A 1), d(A 2), \ldots, d(A n))^{T}
$$

where $W$ is a non fuzzy number.

\section{FINDINGS AND DISCUSSIONS}

This study is handled for the energy strategy decision making problem to help energy investors to determine the optimal renewable energy investment project. Among many critical success factors included in the literature, the ones most suitable 
for the companies operating in the energy sector were selected. 4 critical success factors and 5 renewable energy sources have been determined from the literature. From this standpoint, survey is conducted to obtain data to gather preferences of energy experts working in company operated energy sector via questionnaire. The FANP based approach, which is implemented to select the optimal renewable energy investment project, is composed of following steps.

Step 1. 4 Critical Success Factors and 5 Renewable Energy Sources are identified from the literature review as shown in Table 4. The network structure is also shown in Figure 2. There exists interactions between all criteria and the alternatives. However, there is no interaction among alternatives.

\section{Figure 2: Constructed Analytic Network Structure}

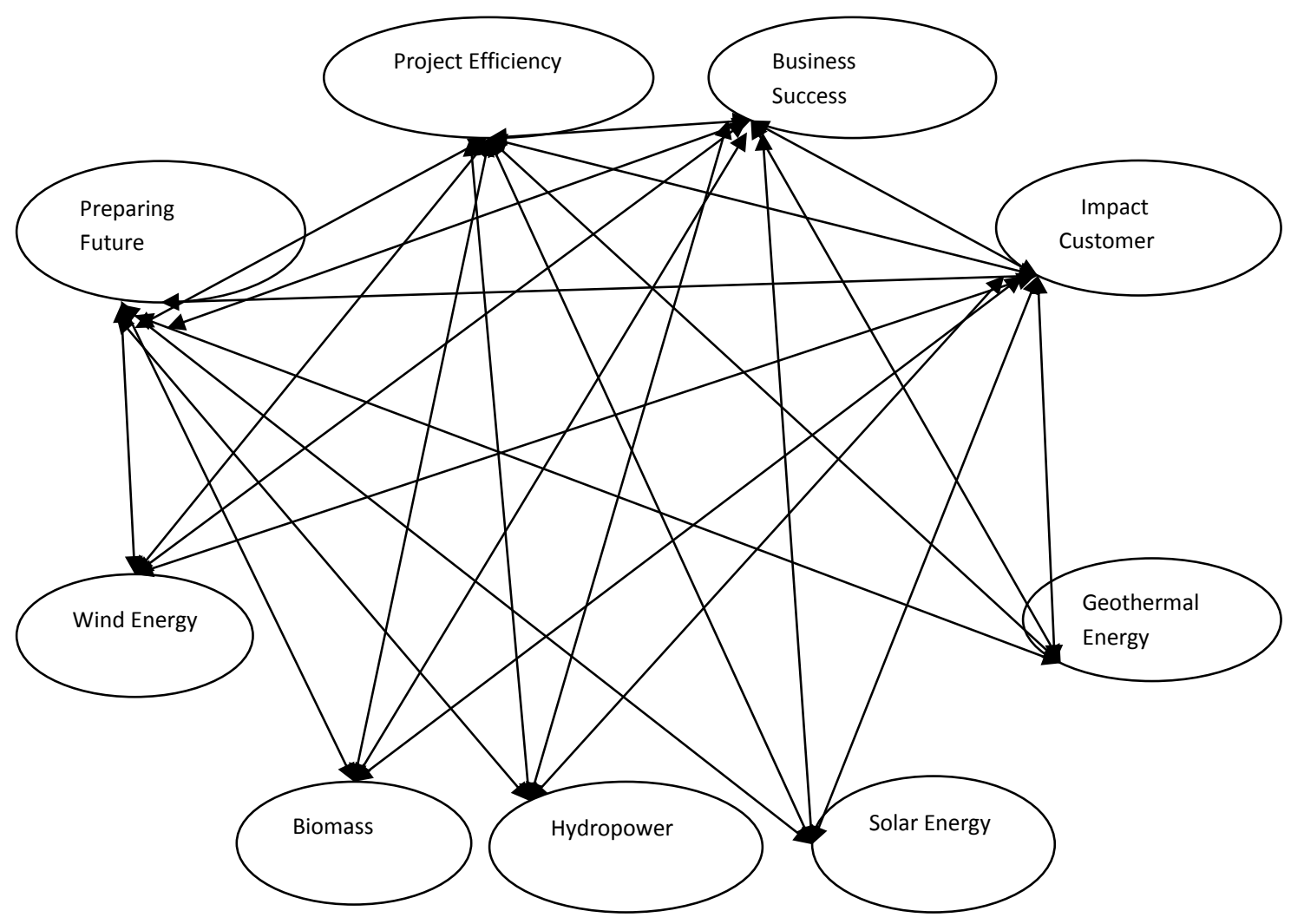

Step2. Pairwise comparisons were carried out according to survey conducted considering preferences of energy experts. Pairwise comparisons were carried out for each evaluation framework node. Each rated score in the questionnaire corresponds to each matrix of criteria. Each pairwise comparison rating is based on Saaty's nine-point priority scale. The linguistic scales include "equally important," "weakly important," "essentially important," "very strongly important," and "absolutely important" with respect to fuzzy level scale. Afterwards, the steps of Chang's extent analysis approach were carried out. The values of fuzzy synthetic degree were used for calculating the importance weights of alternatives. Then, the probabilities of preference an object was found. The combination of probabilities introduces the weight vector. The weight vectors are normalized. The normalized version of weight vectors are the values which are utilized when choosing alternatives. The normalized version of weight vectors are used to establish Initial Matrix for Fuzzy ANP method. 
Table 3: Pairwise Comparisons According to Control Hierarchy

\begin{tabular}{|c|c|c|c|c|c|c|c|c|c|c|}
\hline & \multicolumn{4}{|c|}{ CRITERIA } & \multicolumn{5}{|c|}{ ALTERNATIVES } \\
\hline & & \multicolumn{4}{|c|}{ Critical Success Factors } & \multicolumn{5}{|c|}{ Renewable Energy Sources } \\
\hline & & $\begin{array}{l}\text { Project } \\
\text { Efficiency }\end{array}$ & $\begin{array}{c}\text { Impact } \\
\text { Customer }\end{array}$ & $\begin{array}{l}\text { Business } \\
\text { Success }\end{array}$ & $\begin{array}{l}\text { Preparing } \\
\text { Future }\end{array}$ & $\begin{array}{l}\text { Hydro } \\
\text { power }\end{array}$ & Biomass & $\begin{array}{c}\text { Geo } \\
\text { Thermal } \\
\text { Energy }\end{array}$ & $\begin{array}{l}\text { Solar } \\
\text { Energy }\end{array}$ & $\begin{array}{l}\text { Wind } \\
\text { Energy }\end{array}$ \\
\hline \multirow{4}{*}{ 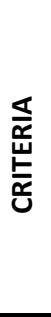 } & $\begin{array}{l}\text { Project } \\
\text { Efficiency }\end{array}$ & 0 & $x$ & $\mathrm{x}$ & $x$ & $x$ & $x$ & $x$ & $x$ & $x$ \\
\hline & $\begin{array}{l}\text { Impact } \\
\text { Customer }\end{array}$ & $x$ & 0 & $x$ & $x$ & $x$ & $x$ & $x$ & $x$ & $x$ \\
\hline & $\begin{array}{l}\text { Business } \\
\text { Success }\end{array}$ & $x$ & $x$ & 0 & $x$ & $x$ & $\mathrm{x}$ & $x$ & $x$ & $x$ \\
\hline & $\begin{array}{l}\text { Preparing } \\
\text { Future }\end{array}$ & $x$ & $x$ & $\mathrm{x}$ & 0 & $x$ & $\mathrm{x}$ & $x$ & $x$ & $x$ \\
\hline \multirow{5}{*}{ 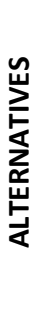 } & Hydropower & $x$ & $x$ & $x$ & $x$ & 0 & 0 & 0 & 0 & 0 \\
\hline & Biomass & $x$ & $\mathrm{x}$ & $x$ & $\mathrm{x}$ & 0 & 0 & 0 & 0 & 0 \\
\hline & $\begin{array}{l}\text { Geothermal } \\
\text { Energy }\end{array}$ & $x$ & $x$ & $x$ & $\mathrm{x}$ & 0 & 0 & 0 & 0 & 0 \\
\hline & Solar Energy & $x$ & $x$ & $x$ & $x$ & 0 & 0 & 0 & 0 & 0 \\
\hline & Wind Energy & $x$ & $x$ & $x$ & $\mathrm{x}$ & 0 & 0 & 0 & 0 & 0 \\
\hline
\end{tabular}

Step 3 After all comparisons and weighting processes were performed, super matrix is obtained. All the components of the network are located horizontally and vertically in super matrix.0 indicates that there isn't an impact of criteria or alternatives on other criteria and alternatives.

Table 4 shows initial super matrix, which was obtained from pairwise comparisons, indicating how much influence of elements to each other. However, these data are not available for providing a useful information.

Table 4: Initial Super Matrix

\begin{tabular}{|c|c|c|c|c|c|c|c|c|c|c|}
\hline & \multicolumn{4}{|c|}{ CRITERIA } & \multicolumn{5}{|c|}{ ALTERNATIVES } \\
\hline & & \multicolumn{4}{|c|}{ Critical Success Factors } & \multicolumn{5}{|c|}{ Renewable Energy Sources } \\
\hline & & $\begin{array}{l}\text { Project } \\
\text { Efficiency }\end{array}$ & $\begin{array}{l}\text { Impact } \\
\text { Customer }\end{array}$ & $\begin{array}{l}\text { Business } \\
\text { Success }\end{array}$ & $\begin{array}{l}\text { Preparing } \\
\text { Future }\end{array}$ & Hydropower & Biomass & $\begin{array}{c}\text { Geothermal } \\
\text { Energy }\end{array}$ & $\begin{array}{l}\text { Solar } \\
\text { Energy }\end{array}$ & $\begin{array}{l}\text { Wind } \\
\text { Energy }\end{array}$ \\
\hline \multirow{4}{*}{ 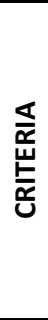 } & \begin{tabular}{|l|} 
Project \\
Efficiency
\end{tabular} & 0 & 0 & 0 & 1 & 0 & 0 & 0 & 0 & 0 \\
\hline & $\begin{array}{l}\text { Impact } \\
\text { Customer }\end{array}$ & 0,244 & 0 & 0,146 & 0 & 0,232 & 0,077 & 0,232 & 0 & 0,256 \\
\hline & $\begin{array}{l}\text { Business } \\
\text { Success }\end{array}$ & 0 & 0,146 & 0 & 0 & 0 & 0 & 0 & 0,242 & 0 \\
\hline & $\begin{array}{l}\text { Preparing } \\
\text { Future }\end{array}$ & 0,756 & 0,854 & 0,854 & 0 & 0,768 & 0,923 & 0,768 & 0,758 & 0,744 \\
\hline \multirow{5}{*}{ 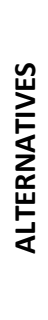 } & Hydropower & 0 & 0 & 0 & 0,551 & 0 & 0 & 0 & 0 & 0 \\
\hline & Biomass & 0 & 0 & 0,544 & 0,231 & 0 & 0 & 0 & 0 & 0 \\
\hline & \begin{tabular}{|l} 
Geothermal \\
Energy
\end{tabular} & 0 & 0 & 0,228 & 0,219 & 0 & 0 & 0 & 0 & 0 \\
\hline & Solar Energy & 0,592 & 0,592 & 0,228 & 0 & 0 & 0 & 0 & 0 & 0 \\
\hline & \begin{tabular}{|l|} 
Wind \\
Energy
\end{tabular} & 0,408 & 0,408 & 0 & 0 & 0 & 0 & 0 & 0 & 0 \\
\hline & & 2 & 2 & 2 & 2 & 1 & 1 & 1 & 1 & 1 \\
\hline
\end{tabular}


Initial super matrix should be reduced to a matrix before taking the limit, where each of its column sums correspond to unity, which will result in a matrix that is called a column stochastic matrix. The outcome is a stochastic super matrix. There exists convergence property of stochastic matrices.

Table 5 indicates normalized super matrix. Stochastic matrices are multiplied numerous times in turn, until the columns stabilize and become identical in each block of stochastic matrices.

Table 5: Normalized Super Matrix

\begin{tabular}{|l|c|c|c|c|c|c|c|c|c|}
\cline { 2 - 10 } & \multicolumn{4}{c|}{ Critical Success Factors } & \multicolumn{5}{c|}{ ALTERNATIVES } \\
\cline { 2 - 11 } & $\begin{array}{c}\text { Project } \\
\text { Efficiency }\end{array}$ & $\begin{array}{c}\text { Impact } \\
\text { Customer }\end{array}$ & $\begin{array}{c}\text { Business } \\
\text { Success }\end{array}$ & $\begin{array}{c}\text { Preparing } \\
\text { Future }\end{array}$ & Hydropower & Biomass & $\begin{array}{c}\text { Geothermal } \\
\text { Energy }\end{array}$ & $\begin{array}{c}\text { Solar } \\
\text { Energy }\end{array}$ & $\begin{array}{c}\text { Wind } \\
\text { Energy }\end{array}$ \\
\hline $\begin{array}{l}\text { Project } \\
\text { Efficiency }\end{array}$ & 0 & 0 & 0 & 0,5 & 0 & 0 & 0 & 0 & 0 \\
\hline $\begin{array}{l}\text { Impact } \\
\text { Customer }\end{array}$ & 0,122 & 0 & 0,073 & 0 & 0,232 & 0,077 & 0,232 & 0 & 0,256 \\
\hline $\begin{array}{l}\text { Business } \\
\text { Success }\end{array}$ & 0 & 0,073 & 0 & 0 & 0 & 0 & 0 & 0,242 & 0 \\
\hline $\begin{array}{l}\text { Preparing } \\
\text { Future }\end{array}$ & 0,378 & 0,427 & 0,427 & 0 & 0,768 & 0,923 & 0,768 & 0,758 & 0,744 \\
\hline Hydropower & 0 & 0 & 0 & 0,275 & 0 & 0 & 0 & 0 & 0 \\
\hline Biomass & 0 & 0 & 0,272 & 0,115 & 0 & 0 & 0 & 0 & 0 \\
\hline $\begin{array}{l}\text { Geothermal } \\
\text { Energy }\end{array}$ & 0 & 0 & 0,114 & 0,109 & 0 & 0 & 0 & 0 & 0 \\
\hline Solar Energy & 0,296 & 0,296 & 0,114 & 0 & 0 & 0 & 0 & 0 & 0 \\
\hline $\begin{array}{l}\text { Wind } \\
\text { Energy }\end{array}$ & 0,204 & 0,204 & 0 & 0 & 0 & 0 & 0 & 0 & 0 \\
\hline
\end{tabular}

Limited super matrix is obtained by multiplying numerous times in turn, until the columns stabilize and become identical in each block of weighted super matrix. Normalized super matrix is used instead of weighted Super Matrix. Since our network model requires normalizing the initial super matrix to keep it to be column stochastic. Then, the normalized super matrix can be raised to limiting powers to calculate the overall priorities.

Limiting value in the row indicates the overall priorities of element in that row. The best alternative which has the highest overall priority was obtained and the best selection criterion with the highest overall priority which affects the selection problem was obtained. To obtain the limited super matrix, $19^{\text {th }}$ power of normalized super matrix was taken. This last matrix was the limited super matrix. Limited super matrix is shown in Table 6. If all columns have the same value, indicating an incorrect result. When we analyze any column, we can see the real weights in the network.

Table 6: Limited Super Matrix

\begin{tabular}{|c|c|c|c|c|c|c|c|c|c|}
\hline & \multicolumn{4}{|c|}{ CRITERIA } & \multicolumn{5}{|c|}{ ALTERNATIVES } \\
\hline & \multicolumn{4}{|c|}{ Critical Success Factors } & \multicolumn{5}{|c|}{ Renewable Energy Sources } \\
\hline & $\begin{array}{c}\text { Project } \\
\text { Efficiency }\end{array}$ & $\begin{array}{l}\text { Impact } \\
\text { Customer }\end{array}$ & $\begin{array}{l}\text { Business } \\
\text { Success }\end{array}$ & $\begin{array}{l}\text { Preparing } \\
\text { Future }\end{array}$ & Hydropower & Biomass & $\begin{array}{c}\text { Geothermal } \\
\text { Energy }\end{array}$ & $\begin{array}{l}\text { Solar } \\
\text { Energy }\end{array}$ & $\begin{array}{l}\text { Wind } \\
\text { Energy }\end{array}$ \\
\hline $\begin{array}{c}\text { Project } \\
\text { Efficiency }\end{array}$ & 0,188 & 0,188 & 0,188 & 0,188 & 0,188 & 0,188 & 0,188 & 0,188 & 0,188 \\
\hline $\begin{array}{c}\text { Impact } \\
\text { Customer }\end{array}$ & 0,077 & 0,077 & 0,077 & 0,077 & 0,077 & 0,077 & 0,077 & 0,077 & 0,077 \\
\hline $\begin{array}{l}\text { Business } \\
\text { Success }\end{array}$ & 0,025 & 0,025 & 0,025 & 0,025 & 0,025 & 0,025 & 0,025 & 0,025 & 0,025 \\
\hline $\begin{array}{l}\text { Preparing } \\
\text { Future }\end{array}$ & 0,376 & 0,376 & 0,376 & 0,376 & 0,376 & 0,376 & 0,376 & 0,376 & 0,376 \\
\hline Hydropower & 0,104 & 0,104 & 0,104 & 0,104 & 0,104 & 0,104 & 0,104 & 0,104 & 0,104 \\
\hline Biomass & 0,050 & 0,050 & 0,050 & 0,050 & 0,050 & 0,050 & 0,050 & 0,050 & 0,050 \\
\hline
\end{tabular}




\begin{tabular}{|c|c|c|c|c|c|c|c|c|c|}
$\begin{array}{c}\text { Geothermal } \\
\text { Energy }\end{array}$ & 0,044 & 0,044 & 0,044 & 0,044 & 0,044 & 0,044 & 0,044 & 0,044 & 0,044 \\
\hline Solar Energy & 0,081 & 0,081 & 0,081 & 0,081 & 0,081 & 0,081 & 0,081 & 0,081 & 0,081 \\
\hline $\begin{array}{c}\text { Wind } \\
\text { Energy }\end{array}$ & 0,054 & 0,054 & 0,054 & 0,054 & 0,054 & 0,054 & 0,054 & 0,054 & 0,054 \\
\hline
\end{tabular}

Step 4. Finally, after the supermatrix is assured of column stochastic, it is raised to a sufficient large power until convergence occurs. That is, the super matrix is then raised to limiting powers to be $W^{2 n+1}$, where $n$ is an arbitrarily large number capturing all interactions and obtains a steady-state outcome. Then, the alternative with the highest overall priority should then be selected.

To normalize every column in the limited super matrix, last priorities in terms of alternatives are introduced and the alternative which has the highest value is chosen as the best alternative. Normalized values of alternatives are shown in Table 7, indicating the optimal renewable energy investment project is hydropower with $31 \%$ of importance. In other words, After FANP method had been implemented for the considered problem, Hydropower with $31 \%$ of importance is selected as optimum renewable energy investment project for the firm.

Table 7: Results

\begin{tabular}{|l|c|c|}
\hline Alternatives & Limited Values & Real Values \\
\hline Hydropower & 0,10368 & $\mathbf{0 , 3 1}$ \\
\hline Biomass & 0,05026 & 0,15 \\
\hline Geothermal Energy & 0,04402 & 0,13 \\
\hline Solar Energy & 0,08137 & 0,24 \\
\hline Wind Energy & 0,05401 & 0,16 \\
\hline
\end{tabular}

\section{CONCLUSION}

When there is interdependence among criteria and alternatives, ANP is an effective tool incorporating interactions among the elements of a decision problem. However, FANP has some further advantages according to the conventional ANP method. It provides more realistic results in pairwise comparison process.

In this study, Fuzzy ANP model for optimum renewable energy investment project has been proposed with an application of the proposed framework constructed for a real renewable energy investment project selection problem. In conclusion, this study provides a realistic assessment of energy resources and the consideration of the ambiguities presented in the preferences of the decision maker. The results of the implementation were informed to energy experts and positive opinions were declared by the decision maker. It has to be taken into account that establishment of pairwise comparisons and network structure are important issues. Data collection from energy experts reflecting their preferences is also significant issue.

It has to be emphasized that the model presented here does not consider all the possible criteria and strategies associated with renewable energy investment project selection. The criteria, strategies and interactions between the criteria and strategies presented in the framework are specific to a particular organization. The methodology utilized in this study can easily be adapted to different situations by adjusting the selection criteria and strategies.

At the end of this study, it must be highlighted that for this kind of studies; decision maker should examine and analyze the situation of his/her firm, and decide to the most appropriate decision making method to make an appropriate and correct implementation.

\section{REFERENCES}

Beccali M. et al(2003). Decision-making in energy planning. Application of the Electre method at regional level for the diffusion of renewable energy technology. Renewable Energy 28 2063-2087.

Benli H. (2013) "Potential of renewable energy in electrical energy production and sustainable energy development of Turkey: Performance and policies" Renewable Energy 50: 33-46.

Boran, S; Goztepe K. (2010) Development of a Fuzzy Decision Support System for Commodity

Acquisition Using Fuzzy Analytic Network Process. Expert Systems with Applications, 37 1939-1945. 
Chang, D. Y. (1996). Applications of the extent analysis method on fuzzy AHP. European Journal Of Operational Research, 95(3), 649-655.

Dong, M. G., \& Li, S. Y. (2016). Project investment decision making with fuzzy information: A literature review of methodologies based on taxonomy. Journal of Intelligent \& Fuzzy Systems, 30(6), 3239-3252.

Haddad B. et al.(2017) A multi-criteria approach to rank renewables for the Algerian electricity system. Renewable Energy,107, 462-472.

Jefferson, M. (2006). Sustainable energy development: performance and prospects. Renewable Energy, 31(5), 571-582.

Kahraman C et al (2009) A comparative analysis for multiattribute selection among renewable energy alternatives using fuzzy axiomatic design and fuzzy analytic hierarchy process. Energy 34:1603-1616

Kahraman C, Kaya I (2010) A fuzzy multicriteria methodology for selection among energy alternatives. Expert Systems with Applications 37:6270-6281

Kaya I, Kahraman C (2010) Multicriteria renewable energy planning using an integrated fuzzy VIKOR \& AHP methodology: The case of Istanbul. Energy 35: 2517-2527.

Kaya I, Kahraman C (2011) Multicriteria decision making in energy planning using a modified fuzzy TOPSIS Methodology. Expert Systems with Applications 38:6577-6585.

Lin ,C.T.; Lee, C. and Wu, C.S (2009) Optimizing a Marketing Expert Decision Process for the Private Hotel. Expert Systems with Applications 36 5613-5619.

Mohanty, R. P., Agarwal, R., Choudhury, A. K., \& Tiwari, M. K. (2005). A fuzzy ANP-based approach to R\&D project selection: a case study. International Journal of Production Research, 43(24), 5199-5216.

Noorollahi Y., Yousefi H. and Mohammadi M.,"Multi-criteria decision support system for wind farm site selection using GIS" Sustainable Energy Technologies and Assessments 13 (2016), 38-50.

Promentilla, M. A. B., Furuichi, T., Ishii, K., \& Tanikawa, N. (2008). A fuzzy analytic network process for multi-criteria evaluation of contaminated site remedial countermeasures. Journal of Environmental Management, 88(3), 479-495.

Saaty, T. L. (2005) Theory and applications of the analytic network process RWS Publications, Pittsburgh.

Saaty, T. L., \& Vargas, L. G. (2006). Decision making with the analytic network process. Springer Science Business Media, LLC.

Stein Eric W. (2013) A comprehensive multi-criteria model to rank electric energy production technologies. Renewable and Sustainable Energy Reviews, 22 (2013).640-654.

Taha, R. A., \& Daim, T. (2013). Multi-criteria applications in renewable energy analysis, a literature review. In Research and Technology Management in the Electricity Industry (pp. 17-30). Springer London.

Tasri A. and Susilawati A.(2014). Selection among renewable energy alternatives based on a fuzzy analytic hierarchy process in Indonesia. Sustainable Energy Technologies and Assessments 7 (2014), 34-44.

Troldborg M. et al. (2014) Assessing the sustainability of renewable energy technologies using multi-criteria analysis: Suitability of approach for national-scale assessments and associated uncertainties. Renewable and Sustainable Energy Reviews 39 (2014)1173-1184.

Zhang et al (2015) Evaluating clean energy alternatives for Jiangsu, China: An improved multi-criteria decision making method. Energy 90 : 953-964.

Zhou, X. (2012). Fuzzy analytical network process implementation with matlab. MATLAB-A fundamental tool for scientific computing and engineering applications, 3, 133-160.

Zhu, K. J., Jing, Y., \& Chang, D. Y. (1999). A discussion on extent analysis method and applications of fuzzy AHP. European Journal Of Operational Research, 116(2), 450-456. 